\title{
The Effect of Portable Electrical Motor Trainer Motor Media To Enhancing Creative And Critical Ability
}

\author{
Hisbulloh Ahlis Munawi ${ }^{1, a^{\star}}$ Agus Suwardono ${ }^{1, b}$ \& Elsanda Merita Indrawati ${ }^{1, c}$ \\ ${ }^{1}$ Faculty of Engineering, Universitas Nusantara PGRI Kediri, Indonesia \\ ahlismunawi@unpkediri.ac.id; agussuwardono@unpkediri.ac.id; elsanda@unpkediri.ac.id \\ ${ }^{*}$ Corresponding Author \\ Whatsapp Number [085733191897]
}

How to Cite: Munawi, H.,A., Suwardono, A \& Indrawati, E., M. (2020). The Effect of Portable Electrical Motor Trainer Motor Media To Enhancing Creative And Critical Ability. International Journal for Educational and Vocational Studies, 2(4), 599-606. DOI: https://doi.org/10.29103/ijevs.v2i4.2298

\section{ARTICLE HISTORY}

Received: 15 February 2020

Revised:28 March 2020

Accepted: 17 April 2020

\section{KEYWORDS}

Creative Thinking;

Critical Thinking;

Portable;

Type Electric Motor Control Trainer

\begin{abstract}
The purpose of this study is to determine the effect of using portable electric motor control trainer media on increasing creative thinking skills and critical thinking skills in electrical engineering students. This research is an experimental study using Pretest-Posttest group design. The subject of the study is electrical engineering students at Nusantara University, PGRI Kediri consisting of 27 students. The level of creativity is measured through aspects of fluency, flexibility, authenticity, and elaboration, while aspects of critical thinking ability are by giving simple explanations, building basic skills, giving further explanation, applying strategies and techniques, and concluding. The study determines the increase in creative and critical thinking skills using $\mathrm{N}$-Gain analysis. The result shows that: 1) the students' creative thinking skills are increased by learning using a portable type electric motor control trainer media that was categorized high on aspects of fluency and elaboration, and categorized based on aspects of flexibility and authenticity; 2) the students' critical thinking skills increase after participating in learning by using portable type electric motor control trainer media which is high in the aspects of elementary classification, inference, strategy and tactics, and categorized based on the aspects of basic support and advanced classification.
\end{abstract}

This is an open access article under the CC-BY-SA license.

\section{INTRODUCTION}

At this time the community was faced by the era of industrial revolution 4.0 which led to massive changes in various fields. The impact of the industrial revolution 4.0 era on education, today is not only focuses on how teachers teach and how students respond to learning, but now education must prepare students to be able to deal with three things,: 1) preparing students to be able to work at work which is not available now; 2) preparing students to solve the problem, which does not yet exist at this time; and 3) preparing children to be able to use technology. Based on these three things students are required to have the ability to think critically, creatively, innovatively, communicatively, collaboratively, and confidently.

Creative and critical ways of thinking are the two main things needed in preparing for the era of industrial revolution 4.0, because they have a positive impact on themselves and a positive impact on their environment. Permendikbud No. 81A of 2013 concerning curriculum implementation states that students' future competency are needed, such as communication, creative, and critical abilities. One effort in improving creative thinking skills and critical thinking skills is by renewing learning media that synchronizes the times and in accordance with the technology being applied.

Learning media is a thing that cannot be separated from teaching and learning activities, this is because learning media can influence or benefit teachers and students. For students the use of learning media can provide a stimulus to focus, be independent, skillful and real experience. For teachers learning media is used to ease delivering learning material.

The selection of learning media to synchronize the objectives of the learning goal. Heinich (1996) states that the selection of learning media uses the USSURE principle 
which includes Analyze Learners, State Objectives, Select methods, media, and material, Utilize media and materials, Require learner participation, Evaluate and revise.

In engineering study, the use of learning media is different from learning in other fields, this is because learning in the field of engineering is more focus on the type of not projected learning media, that is real work media, where learning media have a collaborative system with actual tools. Learning media is hardly influence the creativity and critical thinking skills of students, so that in the end it will affect the learning outcomes and student success in the future. The relationship of creativity and critical thinking towards learning outcomes has a very close relationship. Ali and Ansori (2004: 41) state that the development of creativity has a very close relationship with individual cognitive development, since creativity is the embodiment of the work of the brain.

In the field of engineering, especially in since department of electrical engineering study program, there are many learning media used, for example in practicum study, learning media used are lighting installation media trainers and industrial panels. Based on the results of observations and interviews on students, the learning media used in electrical engineering study programs are patent learning media, in which students must do practicum in the same place and cannot move. One of them is that learning media used in practicum subject are industrial electrical panel media.

The advantages of this learning media are the shape, layout, and working system exactly the same as industry panels in the industry, but the weakness of this learning media is that students must practice in the same place because this learning media is patent, besides this learning media not yet equipped with components that have not been installed, so that when students do practicum and make a series of electric motor controller, students will need a long time to install the components first, then create a series of control systems.

This learning media is quite good for teaching and learning process, but this learning media is still lacking in increasing student creativity and critical thinking, this can be seen from the results of observations, where students tend to be less active, lack of ideas or solutions, and have difficulties in presenting the results of their work, students do not discuss the problems faced in doing group assignments.

Based on the background, this study provides portable trainer electric motor as learning media which is efficient to: 1) place efficiency, this media has a practical luggage bag to carry and used in everywhere; 2) efficiency in usage, this learning media is equipped with control system components that have been installed on the trainer so that students can easily install various series of control systems through jumper cables; 3) time efficiency, the time for running the circuit is relatively much faster than the industrial panel learning media that is used as a medium of learning today, because students only need to create a series of control systems without installing the components first; 4) efficiency in maintenance, because this learning media is made of acrelic and wood so that it is easy to clean and check if an error occurs.

The purpose of this study is to determine the affectability in the use of portable type electric motor control trainer media on increasing creative thinking skills and critical thinking skills in electrical engineering students.

\section{METHODS}

The research method is quasi-experimental research with a quantitative approach, which aims to determine the affectability of portable electric motor control trainer media on increasing creative thinking skills and critical thinking skills. This research was conducted on students majoring in electrical engineering study at the University of Nusantara PGRI Kediri. This study research design is One Group Pretest Postest Design, where the research subjects only used one group without a comparison group that was taught using a portable electric motor control trainer media.

Table 1. Research Design

\begin{tabular}{ccc}
\hline Pretest & Treatment & Postest \\
\hline $\mathrm{O}_{1}$ & $\mathrm{X}_{1}$ & $\mathrm{O}_{2}$ \\
\hline
\end{tabular}

(Sources: Sugiyono, 2012: 111).

The instruments used are test instruments for creative thinking skill and critical thinking skill. Assessment aspects of creative thinking skills tests, 1) fluency, 2) originality, 3) elaboration, and 4) flexibility.

Assessment aspects of critical thinking skills tests are 1) formulating problems, 2) giving arguments, 3) making deductions, 4) making inductions, 5) conducting evaluations, 6) deciding and implementing.

The sensitivity index of question are used to find out how well the question distinguishing or measuring the level of creative thinking skill and critical thinking skills before and after learning using a portable electric motor control trainer media. The question item is said to be sensitive if the sensitivity index is about $\geqslant 0.30$.

Data from pretest and posttest creative thinking skills and critical thinking skills were analyzed using N-Gain to determine the increase in creative and critical thinking skills before and after learning by using a portable type electric motor control trainer media, then the results of the $\mathrm{N}$-gain calculation are converted to kritea tables The $\mathrm{N}$-gain is shown in Table 2.

Table 2. Criteria of Normalized Gain

\begin{tabular}{cl}
\hline Score N-Gain & Criteria Normalized Gain \\
\hline $0.70<$ N-Gain & High \\
\hline $0.30 \leq$ N-Gain $\leq 0.70$ & Medium \\
\hline N-Gain $<0.30$ & Low \\
\hline
\end{tabular}

(Sources: Hake, 2007). 


\section{RESULT AND DISCUSSION}

\subsection{Results}

Students creative thinking skills and critical thinking skills are analized by using creative thinking ability tests given before and after learning using a portable type electric motor control trainer media. To determine the quality of test questions about creative thinking skills and critical thinking ability tests, item sensitivity tests were conducted. The results of the sensitivity analysis of items about the creative thinking ability test are shown in Table 3.

Table 3. Sensitivity of items about tests of creative thinking skills

\begin{tabular}{|c|c|c|c|c|c|c|}
\hline \multirow{2}{*}{ No } & \multirow{2}{*}{ Indicator } & \multirow{2}{*}{ Question Item } & \multicolumn{2}{|c|}{$\begin{array}{c}\text { Proportion of Creative Thingking Skill } \\
\text { Aspects }\end{array}$} & \multicolumn{2}{|c|}{ Sensitivity Question Item } \\
\hline & & & Pretes & Postes & Score & Explanation \\
\hline \multirow{2}{*}{1} & \multirow{2}{*}{ Fluency } & 1 & 50.37 & 85.92 & 0.44 & Sensitive \\
\hline & & 2 & 45.92 & 86.66 & 0.51 & Sensitive \\
\hline \multirow{2}{*}{2} & \multirow{2}{*}{ Flexibility } & 3 & 45.92 & 82.96 & 0.62 & Sensitive \\
\hline & & 4 & 48.15 & 82.22 & 0.42 & Sensitive \\
\hline \multirow{2}{*}{3} & \multirow{2}{*}{ Authenticity } & 3 & 43.70 & 77.77 & 0.42 & Sensitive \\
\hline & & 4 & 42.22 & 74.81 & 0.40 & Sensitive \\
\hline \multirow{4}{*}{4} & \multirow{4}{*}{ Elaboration } & 1 & 41.48 & 85.18 & 0.40 & Sensitive \\
\hline & & 2 & 36.29 & 87.40 & 0.47 & Sensitive \\
\hline & & 3 & 48.15 & 85.92 & 0.35 & Sensitive \\
\hline & & 4 & 32.59 & 85.18 & 0.49 & Sensitive \\
\hline
\end{tabular}

In this study the question instrument of creative thinking ability consists of 4 test questions which cover four aspects, namely aspects of fluency, flexibility, authenticity, and elaboration. Based on the results of sensitivity analysis of creative thinking ability test items in Table 3, all aspects of the item test about creative thinking get sensitive criteria. This can be seen from the calculation of the sensitivity test items for all aspects getting a value of $>$ 0.30. In the aspect of flexibility for item number 3 the sensitivity of the item item was higher than the other aspects of the item, while in the elaboration aspect the number 3 item had the lowest item sensitivity value. Furthermore, the results of the sensitivity analysis of items on the critical thinking ability test are shown in Table 4.

Table 4. Sensitivity of items and test results of critical thinking skills

\begin{tabular}{llccccc}
\hline & & \multicolumn{2}{c}{$\begin{array}{c}\text { Proposition of Critical } \\
\text { No. }\end{array}$} & Indicators of Critical Thinking & Item & \multicolumn{2}{c}{ Shinking Skill Aspects } & \multicolumn{2}{c}{ Sensitivity Questions } \\
\cline { 3 - 7 } & & Pretest & Postest & Score & Explanation \\
\hline 1 & Elementary classification & 1 & 59.26 & 89.63 & 0.37 & Sensitive \\
\hline 2 & Basic Support & 2 & 57.78 & 86.67 & 0.35 & Sensitive \\
\hline 3 & Inference & 3 & 51,85 & 88.15 & 0.46 & Sensitive \\
\hline 4 & Advanced Clarification & 4 & 45,19 & 81.48 & 0.34 & Sensitive \\
\hline 5 & Strategy and tactics & 5 & 40 & 84,44 & 0.41 & Sensitive \\
\hline
\end{tabular}

The critical thinking test instrument in this study consist of 5 questions which included 5 aspects of critical thinking, namely elementary classification, basic support, inference, advanced clarification, strategy and tactics. Based on the results of the sensitivity analysis of critical thinking ability test items in Table 4, all aspects of the critical thinking items get the criteria for items that are sensitive. This can be seen from the sensitivity calculation of items for all aspects of critical thinking to get a value of $>0.30$. The results of the item sensitivity to the creative thinking ability test that got the highest item sensitivity value were in the inference aspect of item number 3 and the lowest item sensitivity value was in the advanced clarification aspect in item number 4. After the item sensitivity analysis was finished, the next step namely analyzing the results of creative thinking skills and the results of critical thinking skills analysis using $\mathrm{N}$-gain as shown in Table 5 and Table 6.
The results of the analysis of creative thinking skills in Table 5 show that there is an increase in creative thinking skills with electric motor control trainer learning media. This can be seen in the results of the ability to think creatively on the aspect of getting $\mathrm{N}$-gain score of 0.74 with high criteria, the flexibility aspect of obtaining aN-score. gain of 0.67 with medium criteria, authenticity aspects get $\mathrm{N}$-gain score of 0.58 with moderate criteria, and elaboration aspects get $\mathrm{N}$-gain score of 0.77 with high criteria. The bar diagram results of tests of creative thinking ability and $\mathrm{N}$-gain results of creative thinking skills are shown in Figure 1.

Figure 1 shows the N-gain results of the elaborate aspect of the creative thinking ability test getting the highest $\mathrm{N}$-gain value compared to the other aspects which is equal to 0.77 , while the lowest $\mathrm{N}$-gain value is obtained in the authenticity aspect on the creative thinking ability test which is 0.58 . 
Table 5. Results of Creative Thinking Ability

\begin{tabular}{clllllll}
\hline No. & \multicolumn{1}{c}{ Aspect } & Pretes & Explanation & Postest & Explanation & N-Gain & Explanation \\
\hline 1 & Fluency & 48.15 & Quite Creative & 86.30 & Very Creative & 0.74 & High \\
\hline 2 & Flexibility & 47.04 & Quite Creative & 82.59 & Very Creative & 0.67 & Medium \\
\hline 3 & Authenticity & 42.96 & Quite Creative & 76.30 & Creative & 0.58 & Medium \\
\hline 4 & Elaboration & 39.63 & Not Creative & 85.93 & Very Creative & 0.77 & High \\
\hline
\end{tabular}

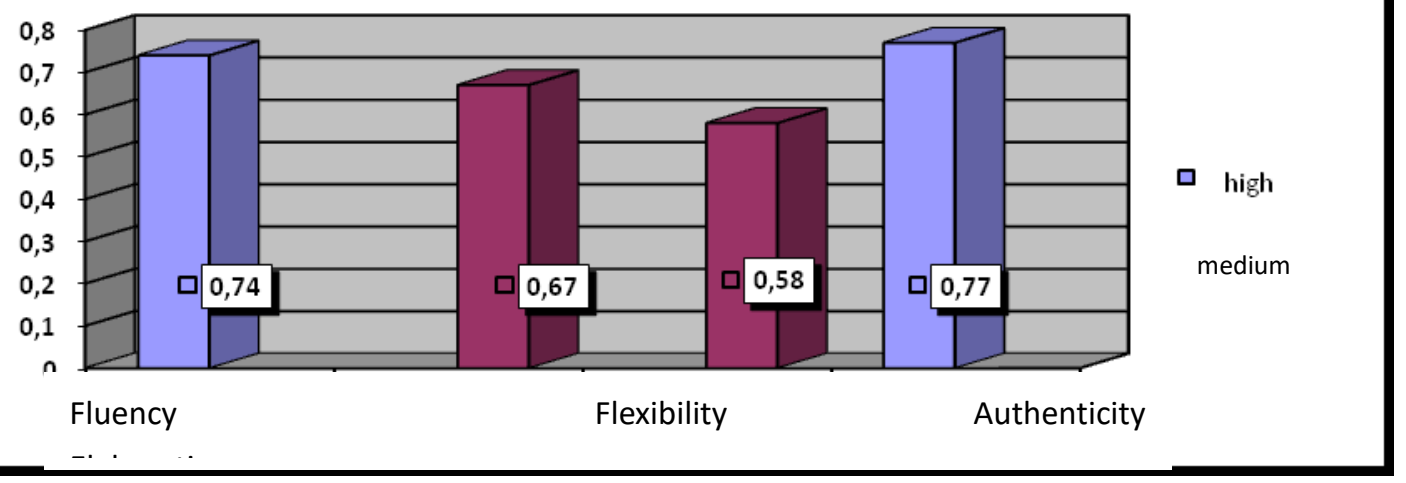

Figure 1. Results of the N-Gain Test of Creative Thinking Ability

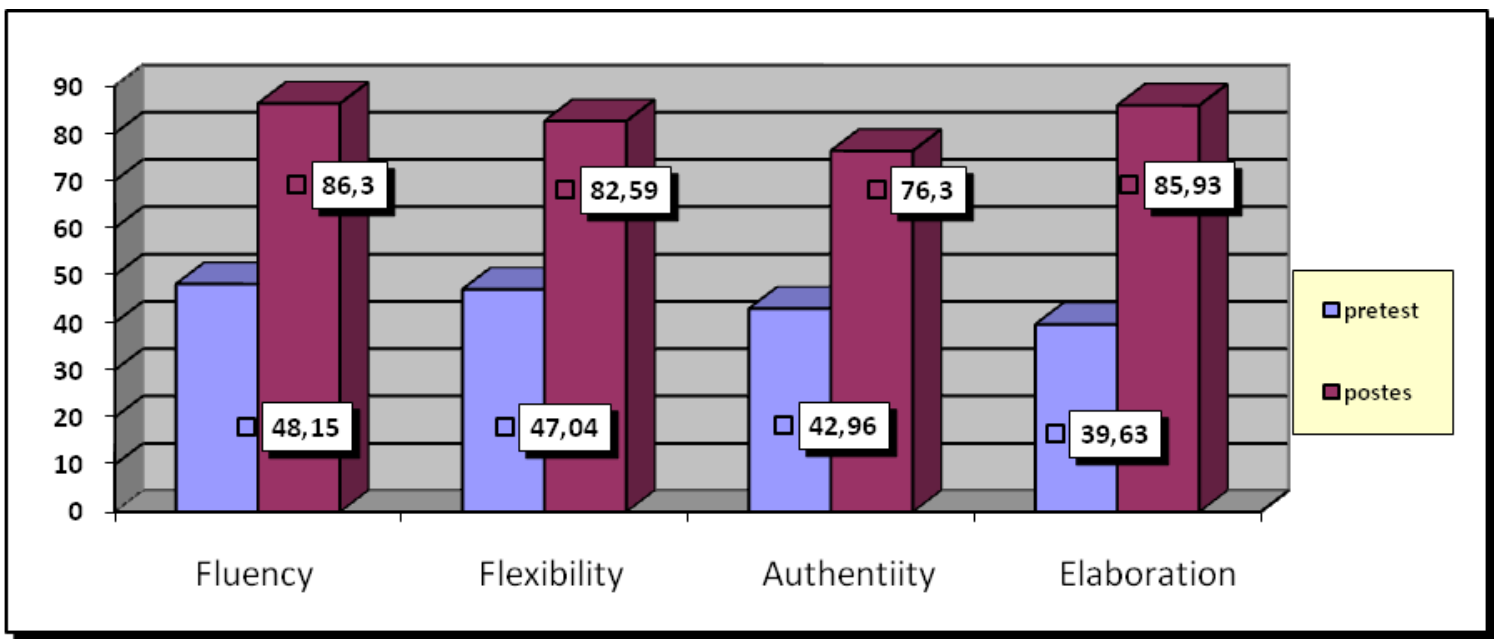

Figure 2. Results of the Critical Thinking Ability Test

Table 6. Results of Critical Thinking Skill

\begin{tabular}{clcccccc}
\hline No & Aspect & Pretes & Explanation & Postes & Explanation & N-Gain & Explanation \\
\hline 1 & Elementary classification & 59.26 & Quite Critical & 89.63 & $\begin{array}{l}\text { Very } \\
\text { Critical }\end{array}$ & 0.75 & High \\
\hline 2 & Basic Support & 57.78 & Quite Critical & 86.67 & $\begin{array}{l}\text { Very } \\
\text { Critical }\end{array}$ & 0.68 & Medium \\
\hline 3 & Inference & 51,85 & Quite Critical & 88.15 & $\begin{array}{l}\text { Very } \\
\text { Critical }\end{array}$ & 0.75 & High \\
\hline 4 & Advanced Clarification & 45,19 & Quite Critical & 81.48 & $\begin{array}{l}\text { Very } \\
\text { Critical }\end{array}$ & 0.66 & Medium \\
\hline 5 & Strategy and tactics & 40 & Not Critical & 84,44 & $\begin{array}{l}\text { Very } \\
\text { Critical }\end{array}$ & 0.74 & High \\
\hline
\end{tabular}

Figure 2 shows that the results of the pretest test of creative thinking ability in the fluency aspect get a weekly value of 48.15 , while the pretest results in the elaboration aspect get the lowest value of 39.63 . The test results of the highest value creative thinking ability were achieved by aspects of fluency with a value of 86.3 , while the lowest results were in the aspect of authenticity, namely getting a value of 76.3

In table 6 shows that there is an increase in critical thinking skills after learning by using a portable trainer. This is evidenced by the N-gain value on the results of creative thinking ability 3 of the 5 aspects of creative thinking skills get high $\mathrm{N}$-gain values that are high in elementary aspects of classification, inference, strategy and 
tactics, while basic support and advance clarification aspects get $\mathrm{N}$-gain with medium criteria.

In Figure 3 shows that the highest $\mathrm{N}$-gain value critical thinking test is achieved by the Elementary classification and inflation aspects with an $\mathrm{N}$-gain value of 0.75 , while the lowest $\mathrm{N}$-gain value is achieved by advanced clarification aspects with an $\mathrm{N}$-gain value of 0.66 .
In Figure 4 shows that the results pretest of creative thinking skill is thet the highest score is achieved by basic aspects of support, while the lowest score of the results of the pretest of critical thinking skills is obtained in the aspects of strategy and tactics. The posttest results show that the highest score of posttest was achieved by aspects of elementary clarification and the lowest posttest score was obtained by advanced clarification aspects.

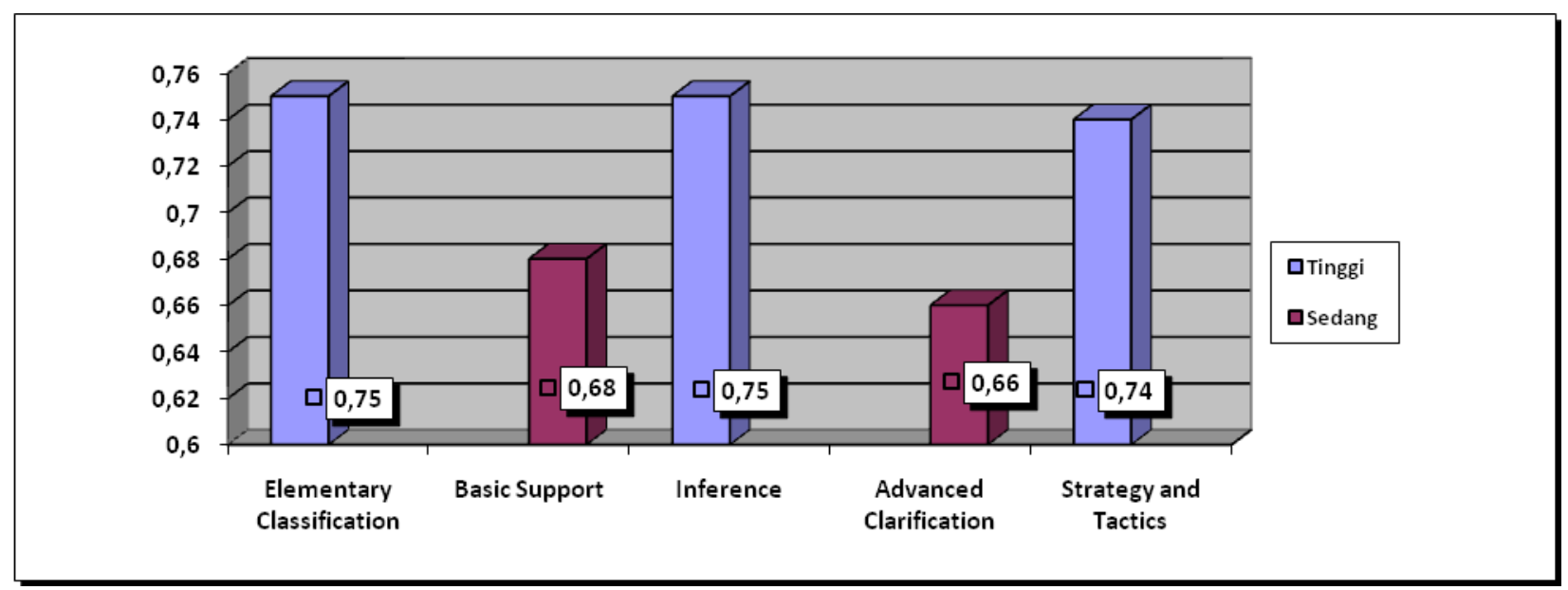

Figure 3. Results of the Gain of the Critical Thinking Skill Test

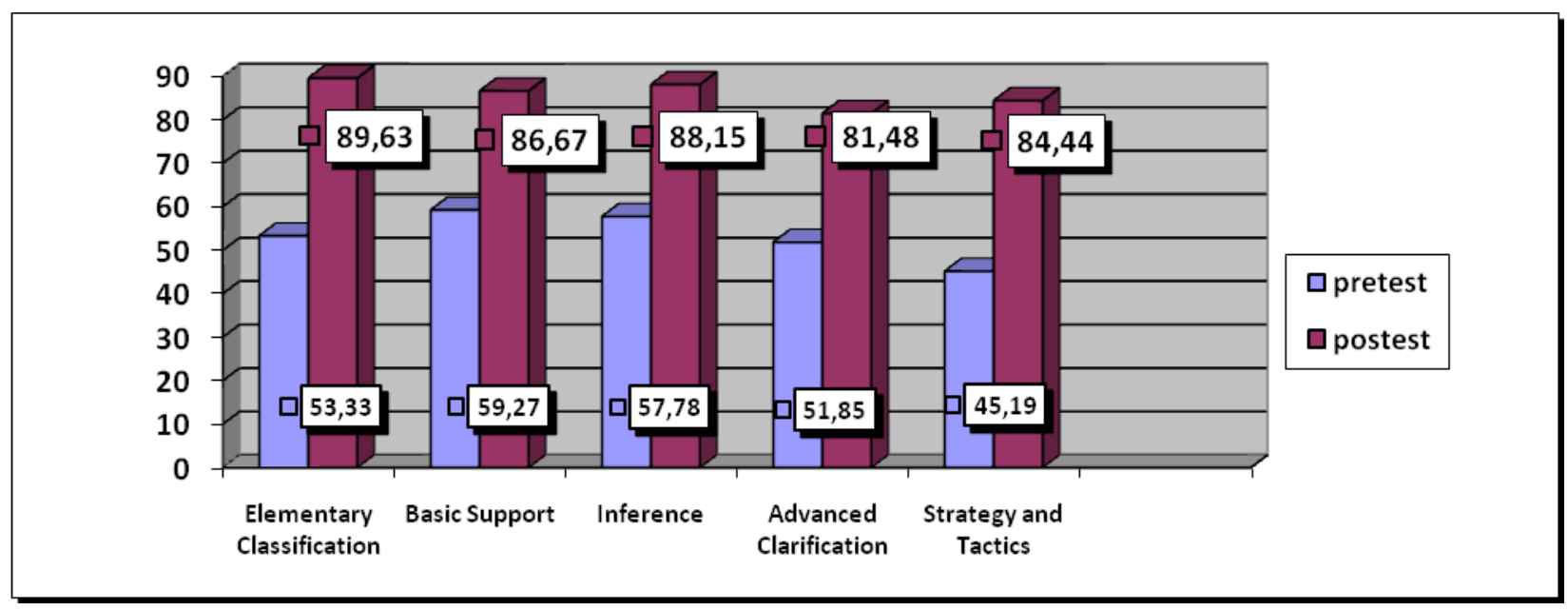

Figure 4. Critical Thinking Skill Test Results

\subsection{Discussions}

The results showed that there was an increase in creative thinking skills and critical thinking skills in students majoring in electrical engineering after carrying out electrical machines trainer using a portable trainer electric motor installation media. The relationship of portable trainer learning media in improving creative thinking skills and critical thinking skills is shown in Table 7 and Table 8.

The learning media of portable electric motor control trainers are made with the aim of increasing creative thinking skills and critical thinking skills of students, this learning media is designed to be a practical, effective and efficient learning media taking into account time efficiency, place efficiency, practicality and effectiveness in use, has a complete component in making various types of control system circuits, and has other advantages, namely this media is easy to install and can be used everywhere because it is portable. In line with that Elfizon, Mukhlidi, and Oriza (2017) state that trainer learning media are practical learning media, because they provide ease of use, time efficiency, are easily interpreted, and have equivalence. In line with Widiantama (2017) conducting research under the title "Development of DC Motor speed control system Trainer as a learning robotics practice Media" found that on the Trainer development resulted in a feasibility assessment for Used for learning at school, so it can be said that trainers are developed worthy to be used as 
a medium for practical learning in school

Learning media portable electric motor control trainer helps students to understand the material of climbing, making it easier for students to make control system sequences with their respective techniques, training students to provide ideas or ideas for problem solving. This is in line with the opinion of Baasito and Tri Rijanto (2018) that media trainers function to clarify subject matter, are easy to use, and have good time efficiency for learning, thus making it easy for students to understand learning and completing assignments.

Learning activities using learning media portable electric motorbike trainers are able to improve creative thinking skills and critical thinking skills of students such as building basic skills, providing simple explanations, strategizing, providing further explanations, and making conclusions through a process of critical thinking. While the findings of Daeng Rahmatullah and Joko (2012) show that media trainers can improve student learning outcomes on cognitive and psychomotor aspects, so that trainers can be said to be suitable for use in learning activities.

Portable electric motor control trainer media can sharpen creative thinking skills and critical thinking skills, making a variety of control systems, find problem solving from problems that arise in the control system that exists in the industry, convey ideas or opinions, provide solutions, produce findings new discoveries in a series of industrial control systems. Besides that portable electric motor control trainer also helps the teacher in delivering material through demonstration activities directly so that students easily understand the material delivered by the teacher. Increased ability to think creatively and students' critical thinking skills directly impact the learning atmosphere to be more active and fun, and learning objectives can also be achieved, so that portable electric motor control trainer media is effective to be used in electrical machine practicum learning because it can improve ability creative thinking and critical thinking skills of students.

Table 8. Relationship of portable trainer learning media in improving skills creative thinking on the material of electric

\begin{tabular}{|c|c|c|c|c|}
\hline No & $\begin{array}{l}\text { Criteria for Selection of Learning Media for Portable Electric motor } \\
\text { control trainer for Increasing Creative Thinking Ability }\end{array}$ & $\begin{array}{c}\text { Indicator of the Instrument } \\
\text { Test for Creative Thinking } \\
\text { Skills }\end{array}$ & $\begin{array}{c}\text { Test } \\
\text { Questions }\end{array}$ & $\begin{array}{l}\text { Creative Thinking } \\
\text { Indicators }\end{array}$ \\
\hline 1 & $\begin{array}{l}\text { Accuracy of media use with learning objectives } \\
\text { - The learning media of portable electric motor control trainers } \\
\text { make it easy and smooth for students to make a variety of electric } \\
\text { motor controller circuits, so that the media is suitable for } \\
\text { achieving the learning objectives of electric machine practicum } \\
\text { courses, one of which is students are able to explain procedures } \\
\text { and work systems }\end{array}$ & $\begin{array}{l}\text { Explain the procedure } \\
\text { and work system of a } \\
\text { complete and correct } \\
\text { electric motor controller } \\
\text { circuit }\end{array}$ & 1 & $\begin{array}{l}\text { Smoothness } \\
\text { Elaboration }\end{array}$ \\
\hline 2 & $\begin{array}{l}\text { Support for the content of learning and ease in obtaining learning } \\
\text { media } \\
\text { - This portable electric motor control trainer is easy to manufacture } \\
\text { because this media utilizes used luggage that is refined using } \\
\text { acrylic and other components that can facilitate students in using } \\
\text { or practicing electrical machines. The learning media of portable } \\
\text { electric motor control trainer is in accordance with the electric } \\
\text { machine practicum learning material because this learning media } \\
\text { can be used to make various electric motor controller circuits, so } \\
\text { as to provide fluency for students in solving problems in existing } \\
\text { electric motor controller problems. in the world of industry }\end{array}$ & $\begin{array}{l}\text { Providing solutions to the } \\
\text { problems that exist in } \\
\text { electric motor controllers } \\
\text { that exist in the world of } \\
\text { industry }\end{array}$ & 2 & Smooth Elaboration \\
\hline 3 & $\begin{array}{l}\text { Skills in using learning media } \\
\text { - Portable electric motor control trainers can hone student skills by } \\
\text { using new strategies in making various electric motor control } \\
\text { circuits such as manual and automatic delta star circuits, manual } \\
\text { and automatic series of forward referrals etc. }\end{array}$ & $\begin{array}{l}\text { Making various series of } \\
\text { electric motor controllers } \\
\text { manual and automatic } \\
\text { star delta circuits. }\end{array}$ & 3 & $\begin{array}{c}\text { Flexibility } \\
\text { Authenticity } \\
\text { Elaboration }\end{array}$ \\
\hline 4. & $\begin{array}{l}\text { Time efficiency and in accordance with the level of thinking of } \\
\text { students } \\
\text { - One of the advantages of portable electric trainer learning media } \\
\text { is that the media is equipped with components in the form of } \\
\text { contactors, TDR, MCB, resistors, timers, and jumper cables and } \\
\text { media in portable form making it easier for students to assemble } \\
\text { electric motor controller circuits, with learning media that are } \\
\text { easy to use and easy to assemble, this gives the impact of more } \\
\text { creative students in learning and conducting experimental } \\
\text { experiments on electric motor control circuits. }\end{array}$ & $\begin{array}{l}\text { - Using a new strategy in } \\
\text { making a series of } \\
\text { electric motor controller }\end{array}$ & 4 & $\begin{array}{l}\text { Using a new } \\
\text { strategy in making a } \\
\text { series of electric } \\
\text { motor controller }\end{array}$ \\
\hline
\end{tabular}


Table 9. Relationship of portable trainer learning media in improving critical thinking skills on the material of electric

\begin{tabular}{|c|c|c|c|c|}
\hline No & $\begin{array}{l}\text { Selection Criteria for Learning Media for Portable Type } \\
\text { Electric motor control trainer }\end{array}$ & $\begin{array}{l}\text { Indicators of Critical Thinking } \\
\text { Skills Test Instruments }\end{array}$ & $\begin{array}{c}\text { Test } \\
\text { Questions }\end{array}$ & $\begin{array}{l}\text { Indicators of } \\
\text { Critical Thinking }\end{array}$ \\
\hline 1 & $\begin{array}{l}\text { Accuracy in the use of media with learning objectives } \\
\text { - Portable electric motor control trainer learning media is } \\
\text { suitable for the learning objectives in the practicum } \\
\text { course in electric machines, one of which is that students } \\
\text { are able to provide explanations and are able to identify } \\
\text { various control circuits in the electrical machine } \\
\text { practicum }\end{array}$ & $\begin{array}{l}\text { Explain and identify the types } \\
\text { of controller circuits by using a } \\
\text { portable electric motor control } \\
\text { trainer learning media }\end{array}$ & 1 & $\begin{array}{l}\text { Elementary } \\
\text { clasification }\end{array}$ \\
\hline \multirow[t]{2}{*}{2} & \multirow[b]{2}{*}{$\begin{array}{l}\text { Support for learning content and ease in obtaining learning } \\
\text { media } \\
\text { - This portable type electric motor control trainer media is } \\
\text { easy to manufacture because it utilizes used suitcases } \\
\text { that are enhanced using acrelic and other components } \\
\text { that can facilitate students in using or practicing } \\
\text { electrical machines, students are able to make a variety } \\
\text { of basic series of motor controllers electricity easily } \\
\text { because the media is equipped with jumper cables, } \\
\text { naming clear symbols on the trainers, and students can } \\
\text { do practical work in various places because this media is } \\
\text { portable. }\end{array}$} & $\begin{array}{l}\text { Making various basic series of } \\
\text { electric motor controllers }\end{array}$ & 2 & Basic Support \\
\hline & & $\begin{array}{l}\text { Concludes the working system } \\
\text { of the electric motor controller } \\
\text { circuit in the practicum of } \\
\text { electric machines }\end{array}$ & 3 & Inference \\
\hline 3. & $\begin{array}{l}\text { Skills in the use of instructional media } \\
\text { - Portable type electric motor control trainer media can } \\
\text { hone students' skills in making a variety of electric motor } \\
\text { control circuits so that this portable type of media trainer } \\
\text { can make it easier for students to solve problems in } \\
\text { electric motor controllers in the industry }\end{array}$ & $\begin{array}{l}\text { Solve problems in electric } \\
\text { motor controllers in the } \\
\text { industrial world. }\end{array}$ & 4 & $\begin{array}{c}\text { Advanced } \\
\text { Clarification }\end{array}$ \\
\hline 4. & $\begin{array}{l}\text { Time efficiency and in accordance with students' level of } \\
\text { thinking } \\
\text { - One of the advantages of portable type electric motor } \\
\text { control trainer learning media is that this media is } \\
\text { already equipped with components in the form of } \\
\text { contactors, TDR, MCB, resistors, timers, as well as } \\
\text { jamper cables and media in a portable form making it } \\
\text { easier for students to assemble electric motor controller } \\
\text { circuits, with a learning media that is easy to use and } \\
\text { easily assembled, this gives the impact of students being } \\
\text { more active in learning and conducting experiments } \\
\text { controlling electric motor circuits. }\end{array}$ & $\begin{array}{l}\text { Provide solutions and } \\
\text { strategies for problems that } \\
\text { exist in the electric motor } \\
\text { controller circuit }\end{array}$ & 5 & $\begin{array}{l}\text { Strategi and } \\
\text { tactics }\end{array}$ \\
\hline
\end{tabular}

\section{CONCLUSION}

Based on the results of the analysis, it can be concluded that 1) students' creative thinking skills increase after carrying out learning using a portable electric motor control trainer media, this is indicated by the results of creative thinking skills that are categorized as fluency and elaboration. flexibility and authenticity, with the value of the average $\mathrm{N}$-gain score of students' creative thinking skills of 0.69 in the medium category; 2) students' critical thinking skills increase after carrying out learning using portable electric motor control trainer media, this is indicated by the results of critical thinking skills which are categorized high in elementary classification, inflation, strategy and tactics aspects, and are categorized as being in basic support and advanced aspects classification, with the value of the average $\mathrm{N}$-gain score of students' critical thinking skills of 0.71 with a high category.

\section{REFERENCES}

Ali, M., \& Ansori, M. (2004). Psikologi Remaja Perkembangan Peserta Didik. Jakarta: Bumi Aksara.

Trimarwan Putra, B. A. A. S. I. T. O., \& Rijanto, T. (2018). Pengembangan Media Trainer Dan Jobsheet Pengasutan Dan Pengereman Motor Listrik Ac 3 Fasa Pada Mata Pelajaran Instalasi Motor Listrik Di Smk Muhammadiyah 2 Taman Sidoarjo. Jurnal Pendidikan Teknik Elektro, $7(3)$.

Daeng, R., \& Joko. (2012). Pengembangan Media Pembelajaran Trainer Multifungsi Pengendali Motor 3 Fasa 220/380 Volt Sistem Dol, F/R, Star-Delta Untuk Mata Pelajaran Kendali Elektromekanik Siswa SMK. Jurnal Pendidikan Teknik Elektro, 1(2), 131-137.

Elfizon., Mukhlidi, M., Oriza, C. Pengembangan Media Trainer Elektromagnetik Dalam Pembelajaran Teknik Elektronika Pada Pendidikan Vokasi Teknik Elektro Fakultas Teknik Universitas Negeri Padang. Seminar Nasional Vokasi dan Teknologi (SEMNASVOKTEK).

Hake. (2007). Design-Based Research in Physics Education Research.: NSF Grant DUE.

Heinich, R., et. Al. (1996). Instructional Madia and Technologies for Learning. New Jersey: Prentice Hall, Englewood Cliffs.

Permendikbud 2013 No. 81, Pendirian Satuan Pendidikan Nonformal. 
Sugiyono. (2011). Metode Penelitian Kuantitatif, Kualitatif dan $R \cap D$. Bandung: Alfabeta.

Widiantama, O. (2017). Pengembangan Trainer Sistem Kendali Kecepatan Motor DC Sebagai Media Pembelajaran Praktik Robotika. E-Journal Pendidikan Teknik Mekatronika, 7(2), 188-196. 